\title{
ANALYSIS OF MACROECONOMIC FLUCTUATIONS IMPACT ON EFFICIENCY AND ISLAMIC BANKING QUALITY 2015-2019
}

\author{
Ana Toni Roby Candra Yudha ${ }^{a}$ \\ Imam Wahyudi Indrawan ${ }^{\text {b }}$ \\ Syarifudin ${ }^{c}$ \\ ${ }^{a}$ Sharia Economics Department, Faculty of Islamic Economics and Business, Sunan Ampel Islamic \\ State University \\ bIslamic Economic Department, University of Airlangga

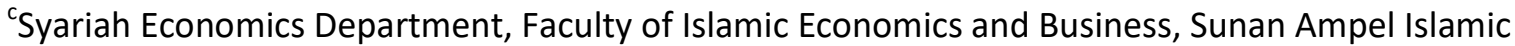 \\ State University \\ Email: anatoniroby@uinsby.ac.id ${ }^{\mathrm{a}}$; $\underline{\text { imamindra58@gmail.com }}^{\mathrm{b}}$; $\underline{\text { udinsyarif1109@gmail.com }}{ }^{\mathrm{C}}$
}

ARTICLE HISTORY
Received:
06 April 2021
Revised
01 September 2021
Accepted:
26 October 2021
Online available:
30 November 2021
Keywords:
Islamic Banking,
Efficiency,
Macroeconomics,
Non-Performing
Finance,
Two-Stages Least
Squares.
*Correspondence:
Name:
Ana Toni Roby
Candra Yudha
E-mail:
anatoniroby@uinsby.
ac.id

ARTICLE HISTORY

Received:

06 April 2021

Revised

01 September 2021

Accepted:

26 October 2021

Online available:

Keywords:

Islamic Banking

Efficiency,

Macroeconomics, Non-Performing

Finance,

Two-Stages Least

*Correspondence:

Name:

Ana Toni Roby

ac.id

\begin{abstract}
This study aims to analyze the impact of macroeconomic shocks, such as economic growth, inflation and the rupiah exchange rate on Islamic banking efficiency. This study uses the two-stage least squares (TSLS) method, which is a method with two endogenous variables, namely the non-performing financing (NPF) ratio as a representation of the quality of Islamic banking financing and the operating expense operating income (BOPO) ratio as a representation of Islamic banking efficiency. So that the TSLS method aims to purify these endogenous variables against stochastic disturbances. This study uses monthly data from January 2010 to January 2020, or as many as 121 observations. The observation of data is obtained from Islamic Banking Statistic that published by Financial Services Authority (OJK). The efficiency of Islamic banks is influenced by the number of sharia banking office networks, capital adequacy ratios, and NPF ratios. The NPF ratio itself is affected by macroeconomic conditions (economic growth and appreciation of the rupiah exchange rate) as well as the efficiency of Islamic banking. Based on the above findings, a number of recommendations were given, including the urgency of simultaneously increasing efficiency and quality of Islamic banking financing accompanied by monitoring Indonesia's macroeconomic conditions, so that it is hoped that Islamic banks will be more resilient to macroeconomic shocks and competitive in the national financial services industry.
\end{abstract}




\section{INTRODUCTION}

Conventional banks operating in any country have a larger market share compared to Islamic banks (Ponziani \& Mariyanti, 2020). Also, they have cost-effective and more stable expenses compared to Islamic banks (Beck et al., 2013). This can occur due to Islamic banks' business orientation (Hardianto \& Wulandari, 2016), stability and risk management (Aulia et al., 2020), which are not as big as conventional banks (Rahmah \& Armina, 2020). In another discourse, it is mentioned about banks in India (Hassan \& Sengupta, 2019), which most people are non-Muslims. The factors that affect the ratio of bad credit or financing (Murti, 2017), non-performing financing or nonperforming loan, are three: the loan period (Olson \& A. Zoubi, 2014), credit/financing objectives (Rahmah \& Armina, 2020), and financial innovation (Dhal \& Misra, 2014). So that based on the empirical findings, it can be interpreted that the efficiency and effectiveness of banking financial performance is influenced by the factors above, such as market share (Alwi, 2018), employee performance, and expenses or operating costs (Hazera et al., 2016).

Regulatory banking efficiency is also regulated in the Bank Indonesia Regulation (PBI) concerning bank soundness assessment. Banks, both conventional and Islamic banks, need to carry out a self-assessment. This must be reported to Bank Indonesia (BI) as the highest monetary authority owner in Indonesia (Bank Indonesia, 2011). As stated in Article 3 of PBI Number 13 of 2011 concerning the assessment of bank soundness (Firianingsih, 2017), banks need to carry out a self-assessment consisting of 4 types of activities, namely risk profile (Şan, 2016), good corporate governance (GCG), profitability (earnings) (Lotto, 2019), and capital.

Banking efficiency is crucial (Miah \& Uddin, 2017). It is essential to measure it, considering that efficiency is one indicator of banking health (Muljawan et al., 2014), both in conventional banks and Islamic banks (Indrawati et al., 2020). Like the measurement of banking efficiency in Japan, banking performance will be maximized if the risk factor is smaller than operating costs (Ding \& Sickles, 2019). There is also a finding that the level of financing or credit is the most significant factor that has the potential to affect efficiency (Sukoco et al., 2020).

Conditions that occur in any state in the world note that the level of banking efficiency is assessed by the number of costs incurred (Zaki et al., 2020), revenue generated (Nguyen et al., 2019), professional performance, and models and risk management methods (Ghosh, 2017). This study also intends to test and analyze the efficiency of banking in Indonesia, especially Islamic banks (Pinochet et al., 2019). Furthermore, this study wants to observe the factors that cause the level of efficiency in Islamic banks in Indonesia, whether there are similarities with factors that occur in the 
world in general, or there could be separate issues and findings on measuring Islamic banks' efficiency in Indonesia.

World conditions that explain the need to measure banking efficiency are necessary (Hadisumarto \& Ismail, 2010). It is the same as Indonesia's banking conditions (Ponziani \& Mariyanti, 2020), especially Islamic banks or Islamic-compliant finance (Sadari \& Hakim, 2019). Islamic banks in Indonesia, since the establishment of Bank Muamalat as the first Islamic bank until the time of this research (Yalina et al., 2020), the growth and development of Islamic banks in terms of assets, human resources, and shares are still not significant (Isa \& Rashid, 2018). Following is the data on the development of Islamic bank offices number for four years from 2015-2019.

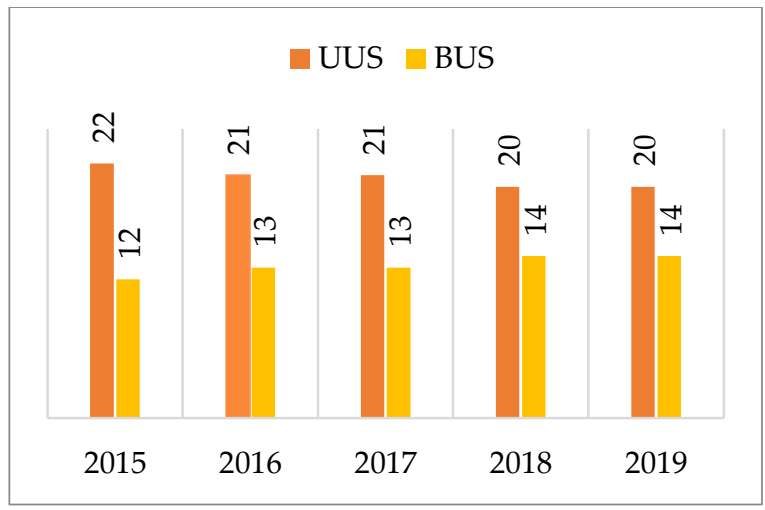

Figure 1. Growth in the number of Islamic Commercial Banks and Islamic Business Unit in Indonesia Source: Statistik Perbankan Syariah (2020)

Based on Figure 1, there is a downward trend in Islamic Business Unit in terms of quantity, while Islamic Commercial Bank has increased in number. However, in terms of the Islamic financial market share in Indonesia, they have come out of the share trap of around 5\% since November 2019. Based on information obtained from the Islamic banking snapshot of the Financial Services Authority (OJK), the share has increased to 6.1 per cent. In 2015, the number of Islamic Commercial Bank was twelve while the Islamic Business Unit was 22. The number of Islamic Commercial Bank experienced an increasing trend in quantity from twelve in 2015 , continues to increase to fourteen in 2019. Indeed, in terms of numbers, it is not too significant, but it should be appreciated. At least this shows an increase in literacy or understanding and public concern for transactions using Islamic banking and financial products and services.

The insignificant development of Islamic banking is suspected due to several aspects. One of these aspects is efficiency. As a financial institution operating for more than a decade and has a massive market potential due to predominantly Muslim society, Islamic banking in Indonesia should know, have, and understand the principles of good corporate governance (GCG) in an Islamic context, including in managing efficiency.

The concept of management in the Islamic field is not a new thing because this concept has existed for a long time in Islamic management (Fatmawati et al., 2020), for 
example, as has been done by the Prophet Muhammad's companions in managing the financial institution, Baitul Maal. However, with the proliferation and development of capitalism's economic principles and the liberalism system introduced by the western world, slowly but surely, the concept of Islamic management has been abandoned by the Muslims.

In the modern era, economic life, especially banking products, is still dominated by consumptive contracts (aqad). This is also the case with Indonesian Islamic banks in general, as evidenced by the report published on the OJK's official website summarized as the histogram below.

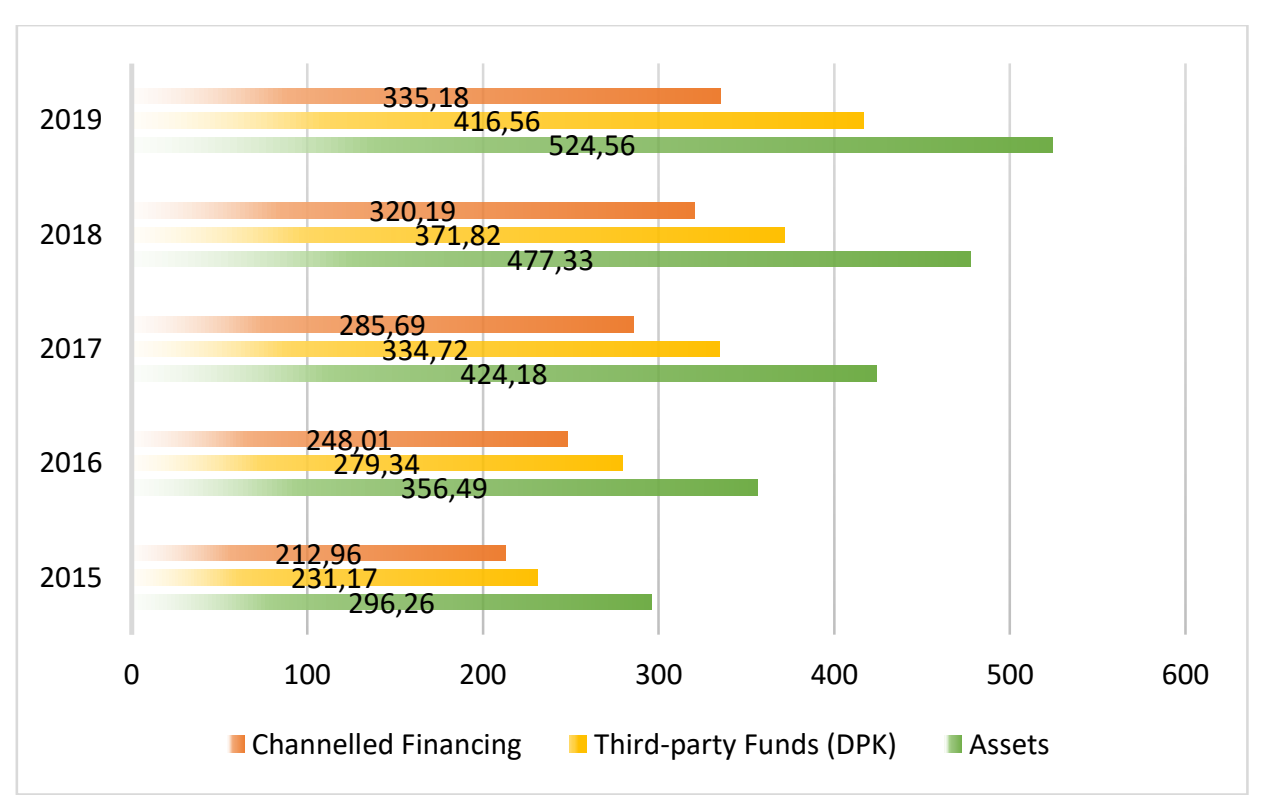

Figure 2. Islamic Banking Performance in Indonesia 2015-2019 (in trillion rupiahs) Source: Islamic Banking Statistics (Processed)

It can be seen from data on Islamic banking performance in Indonesia, as shown in Figure 2 above. Islamic banking performance can be observed from three things: the amount of channelled financing, third-party funds (DPK), and assets. Data showing these three parameters from 2015 to 2019 has generally experienced a steady increase. The increase occurred in channelled financing, deposits and assets, respectively. In 2015, Islamic banking assets amounted to IDR 296.26 trillion, then the number of third-party funds (DPK) was IDR 231.17 trillion, and the amount of channelled financing by Islamic banking in 2015 was IDR 212.96 trillion. This report looks positive, even until 2019, the three parameters have continued to increase. It is proven that until 2019, the asset value of Islamic banking is IDR 524.56 trillion, DPK of IDR 416.56 trillion, and the amount channelled as financing was IDR 335.18 trillion. This indicates that Indonesian Islamic 
banking performance has increased from time to time and has gained a place in Indonesian society in general, as well as in the Muslim community in particular.

The product scheme most in demand by customers in 2017 was murabaha, which was worth 144,329 trillion. It means that people are still interested in consumptive financing compared to productive financing, such as musyarakah and mudharabah. But at least musyarakah and mudhrabah financing occupied the second and third proportions with a value of 91.729 trillion and 16.059 trillion in the same year, respectively (Lee \& Isa, 2017). Customers are interested in productive financing, which is not as large as murabahah financing due to the risk factors for high returns and high operational costs (Effendi et al., 2017).

It turns out that this performance has many obstacles in it. When financing is large, there are also other problems found by Islamic banking, namely the high operating costs (Roy \& Goswami, 2013). Banking operations should also be related to efficiency (Chitnis \& Vaidya, 2018). There is a kind of synergy between the non-performing financing (NPF) ratio and the operating expense and operating income (BOPO) ratio (Yudha et al., 2020), which is further included regarding the efficiency indicators of Islamic banking which are proxied by the two ratio (Akpan et al., 2018).

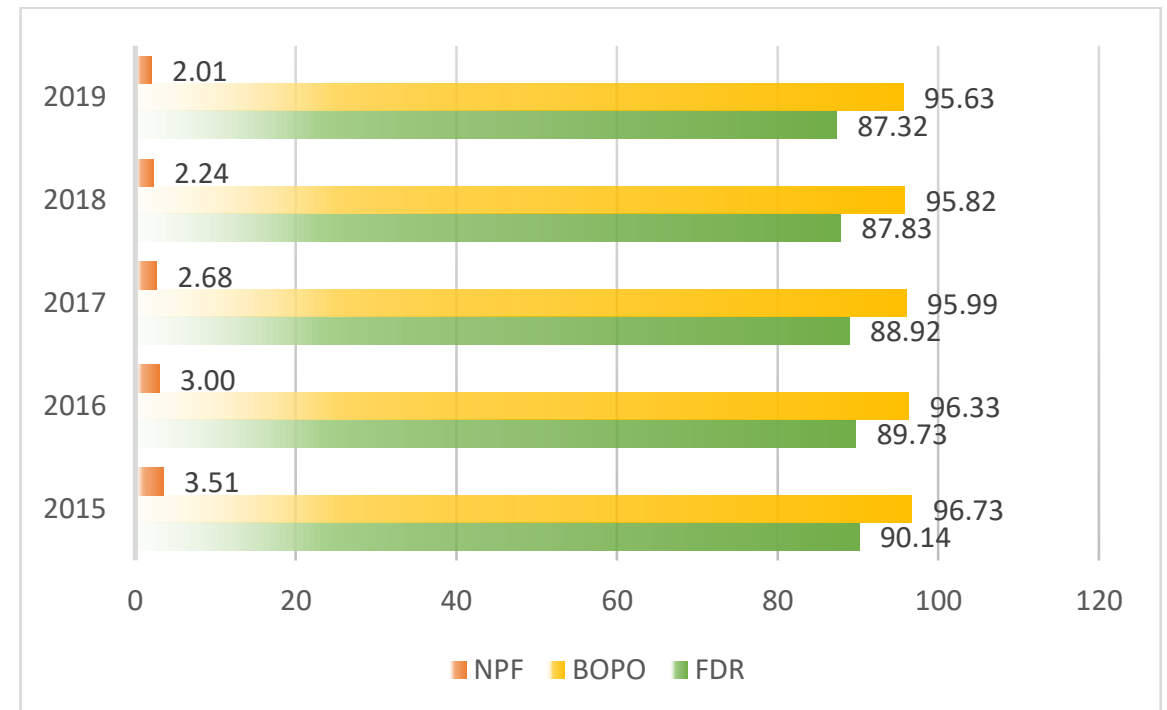

Figure 3 The Quarterly Average of Islamic Commercial Bank Financial Performance 2015-2019 (in percentage)

Source: Islamic Banking Statistics (Processed)

Based on Figure 3 about the average of NPF, BOPO, as well as the financing to deposit ratio or FDR (Hess \& Francis, 2004), it can be observed that the bad debts ratio for the last five years (2015-2019) from Islamic banks is classified as good because it is still around less than 5 per cent. This explains that debtors' repayment is categorized as safe and smooth (Pan et al., 2019). However, another fact that can be seen from the Indonesian Islamic banks' financial health condition in the same span of the year is that 
the ratio of BOPO is still huge, which is more than 85 per cent. It means that the operational conditions of Islamic banks cannot be said to be ideal or inefficient. This probably due to the hypothesis that almost all of the revenue obtained based on the FDR ratio is used for operating costs.

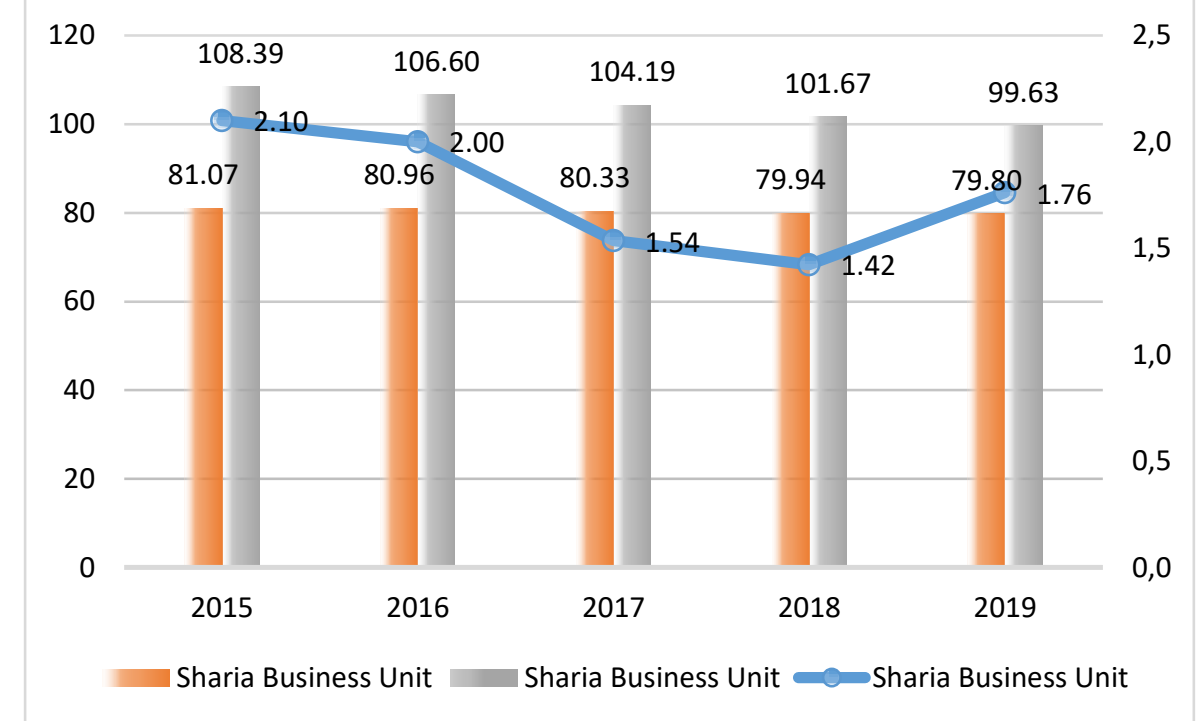

Figure 4. The Quarterly Average of Islamic Business Unit Financial Performance 2015-2019 (in percentage)

Source: Islamic Banking Statistics, processed

Referring to Figure 4 about the quarterly average of the Islamic Business Unit financial performance 2015-2019, there are several influential rations including: the ratio of NPF (Chitnis \& Vaidya, 2018), the ratio of BOPO (Wardiwiyono, 2012), and FDR. The Islamic Business Unit performance is slightly different from the Islamic Commercial Bank that was reviewed in the previous section (Lee \& Isa, 2017). The financing distribution ratio has an average value of 80 per cent, meaning that the Islamic Business Unit is still in great demand by customers. Besides, NPF is only around 2.5 per cent, which means that customers have a high commitment to repaying financing, and customer trust in Islamic Business Unit remains high. This gives its optimism when the Islamic Business Unit FDR reaches above $100 \%$, the average BOPO is $80 \%$, and the NPF is below $2.5 \%$. However, it turns out that behind this good performance, it has not been fully matched by a Islamic Commercial Bank whose operating expense ratio is still relatively high, namely $85 \%$.

This ratio is related to Islamic banking's efficiency, primarily operating expenses to operating income (BOPO). From 2015 to 2019, Islamic banks' BOPO ratio is still high, which is more than $85 \%$, meaning that Islamic banks do not have efficient operating conditions. In this study, the discussion tends to focus more on the efficiency aspects of Islamic banking, given that the analysis process requires measurement of 
macroeconomic fluctuations. Based on previous reviews from beginning to end in the introductory section, it is interesting to conduct a study with the title Analysis of Macroeconomic Fluctuations Impact On Efficiency And Quality Of Islamic Banking 20152019. Accordingly, the formulation of the problem is, what factors affect the efficiency of Islamic banking in Indonesia, and how much influence did macroeconomic fluctuations have on Indonesia's Islamic banking efficiency?

Based on the problem background and the problem formulation, the objectives of this study are to knowing, assessing, and analyzing the factors that affect the efficiency and quality of Islamic banking financing in Indonesia. This study also aims to know, assess, and analyze the economic fluctuation impact on the efficiency and quality of Islamic banking financing in Indonesia.

\section{LITERATURE REVIEW}

\section{Efficiency}

Efficiency generally is frugal in all aspects. Save money in using the resources you have, then use them to get optimal results. efficiency in other sources means that, careful and precise in the use of energy and time. So, the goal of efficiency is to avoid wasteful and detrimental symptoms (Haleem \& Khan, 2017). The determinants of bank efficiency show that the efficiency of the company is influenced by the age, size, location, and industry of the company (Pham et al., 2021). The impact of innovation affects the efficiency of the company (Ramanathan et al., 2018), where macroeconomic conditions facilitate increased efficiency of the company. Phan also shows that bank size, macroeconomics, and market concentration also affect bank efficiency (Habibi \& Yudha, 2017), while competition and liquidity risks are negative (Phan et al., 2016).

Efficiency also applies to institutions, for example, banking efficiency. Banking efficiency can be classified into scale efficiency, scope efficiency, technical efficiency, and allocative efficiency (Roy \& Goswami, 2013). Banks can be said to be efficient when they can operate in a constant returns scale (IImu \& Indonesia, 2012). Meanwhile, scope efficiency is achieved when banks can operate in locations capable of diversification (Noordin et al., 2017). In China, intuitively evaluating bank efficiency has an important role in providing policy implications to managers and decision makers. Problems related to banking efficiency have long been emphasized in the literature, where financial ratio analysis is one of the factors that has been applied to find production or cost limits and analyze productivity efficiency (Yin et al., 2018). Even, a production can be considered efficient when using a certain amount of input can produce maximum output or by using minimal input (Beck et al., 2013). 


\section{Non Performing Financing (NPF)}

Non Performing Financing or NPF is a problem that occurs in the process of submitting an approved internal bank financing, (Cucinelli, 2016) or after the funding is provided. NPF and NPL occur in different systems (Yudha, Ryandono, et al., 2020). The Islamic banking system has fundamental factors that can prevent the emergence of the NPF from growing; however, the conventional banking system also provided more significant opportunities. As a substitute for interest, Islamic banks focus on obtaining benefits from transactions with their partners (Sadari \& Hakim, 2019).

The higher the NPL level, the greater the credit risk borne by the bank. As a result, the insurer will be more selective and careful in distributing credit, it is feared that partners will default (Prahasty \& Misdiyono, 2020). The high NPL also indicates the declining health of the bank and has an impact on the decline in the level of lending (Rabab'ah, 2015).

Management of public funds by banks in both conventional and Islamic banking can be assessed as debt (Noman et al., 2017). It means that Islamic banks do not use the concept of leverage, or in other words, that debt is used to increase profits; but that magnifies the business risk. Because basically, the invested resources will generate returns that are not on the spot, the possibility of running on the bank is smaller. On the other hand, a bank can synergize risk and return between the mudharabah contract and the owner of the fund or shahibul mal (in this case, the Islamic bank plays a role as mudharib). Meanwhile, on the liabilities side, using a mudharabah contract with the customer who is given financing as mudharib (in this case, the Islamic bank becomes shahibul mal), on the asset side. In general, the risk ratio for financing or nonperformance financing (NPF) is stated in the following formula.

$$
\text { NPF }=\frac{\text { Problematic Financing }}{\text { Total Financing }} \times 100 \% \ldots .(1)
$$

\section{Operating Expense Operating Income (BOPO)}

Operating expense operating income (BOPO) is the ratio formed from operating expense to operating income. Operating expense consists of costs incurred on banking activities which include marketing costs, labor costs, and other costs (Roy \& Goswami, 2013). While operating income is the main income of a bank, namely income obtained from the placement of funds in the form of credit or financing and other operating income (Hess \& Francis, 2004). The relationship that is formed between BOPO and the level of efficiency is that the smaller the BOPO, the more efficient the bank is in carrying out its business activities (Akpan et al., 2018), and vice versa. For a bank that has a

Published by University of Airlangga.

This is an open access article under the CC BY license (https://creativecommons.org/licenses/by-nc-sa/4.0/) 
healthy condition, the BOPO ratio is less than one; on the other hand, a less healthy bank, the BOPO ratio is more than one. According to Bank Indonesia regulations, operating efficiency is measured by BOPO (Bank Indonesia, 2011).

The ratio of operating expense is a comparison between operating expense and operating income (Altunbas et al., 2000). The operating expense ratio is used to measure the efficiency level and the ability of the bank to carry out operational activities (Pan et al., 2019). So, the lower BOPO means the more efficient the bank in controlling its operating expense. With the presence of cost efficiency, the bank will get an even greater profit.

$$
\text { BOPO }=\frac{\text { operating Expenses }}{\text { Operating Income }} \times 100 \% \ldots . .(2)
$$

Banking efficiency can be seen from the BOPO ratio. The smaller the value of the BOPO ratio, the better its performance because the bank can meet the operating expense they have to spend with its operating income. Whereas, the greater the ratio value, then the bank's performance will be categorized as bad or inefficient.

The BOPO ratio can also illustrate bank's conditions. First, the ability of a bank's management to manage existing assets to generate maximum profit. The smaller the ratio value, the more efficient the bank's operations are, and the higher the bank's potential to generate profits. Second, the bank's ability to control costs. The smaller the BOPO, the more efficient the bank is in controlling operating expense. The bank's ability to generate profits and minimize operational risks.

\section{Hypothesis}

Based on background, problem formulation, aims, literature review, and previous study. Then. the hypothesis formulated in this study is:

HO : Macroeconomic fluctuations do not impact on the efficiency and quality of sharia banking 2015-2019

H1 : Macroeconomic fluctuation impact on the efficiency and quality of sharia banking 2015-2019

\section{RESEARCH METHODS}

This research was conducted using a quantitative approach; using statistical techniques in carrying out data analysis. This research used three variables: macroeconomic variables, NPF, and BOPO. Among the three variables, the NPF variable can play a dual role because it can be an independent variable for macroeconomic variables and act as a dependent variable for BOPO. This study included an analysis of monthly data starting from January 2010 to January 2020, or as many as 121 
observations. The 121 data are Islamic bank financial ratios that obtained from Financial Services Authority (OJK).

All data used in this study were secondary data obtained from three sources, namely:

1. Financial Services Authority (https://ojk.go.id/), is a source for data related to Islamic banking;

2. Central Bureau of Statistics (https://bps.go.id/), a source for macroeconomic-related data; and

3. Investing.com that is an investment site (https://investing.com) for data regarding the exchange rate of the Rupiah against the United States dollar.

This study used the analysis technique of two-stage least squares (TSLS). This technique is a regression approach used to predict a model that has endogeneity problems, which is a condition when a model consists of more than one equation and one or more variables that are positioned as independent variables in an equation and become dependent variables in other equations (Asteriou \& Hall, 2007). The TSLS approach is considered relevant to resolve this case because the variables used in this study are endogenous. For example, NPF and CAR are still one of the factors of BOPO.

The TSLS model in this study consisted of two models which were analyzed together. Mathematically, it can be written as follows:

$$
\begin{aligned}
\mathrm{BOPO}_{t}=\alpha_{0} & +\alpha_{1} \cdot N P F_{t}+\alpha_{2} \cdot \text { CAR }_{t}+\alpha_{3} \cdot L N_{-} \text {Office }_{t}+\varepsilon_{t} \ldots(3) \\
N P F_{t}=\beta_{0} & +\beta_{1} \cdot L N_{I P I_{t}}+\beta_{2} \cdot L N_{C P I_{t}}+\beta_{3} \cdot L N_{E X R_{t}}+\beta_{6} \cdot L N_{\text {Financing }_{t}}+\beta_{5} . \text { BOPO } \\
& +\mu_{t} \ldots(4)
\end{aligned}
$$

In the two equations above, the BOPO and NPF are two variables that are positioned as endogenous variables because they appear in the two equations above and change positions because they have the potential to influence each other competitively. The operational definition and description of each variable are shown in the following table:

\begin{tabular}{|c|c|c|c|}
\hline Variable & Operational definition & Unit & Coefficient Information \\
\hline $\mathrm{BOPO}_{\mathrm{t}}$ & $\begin{array}{l}\text { Operating Expense - } \\
\text { Operating Income ratio of } \\
\text { Islamic banking in month } t\end{array}$ & Per cent (\%) & $\begin{array}{l}1 \% \text { increase in } \mathrm{BOPOt} \text {, cateris } \\
\text { paribus, will result in a change in } \\
\mathrm{NPF}_{\mathrm{t}} \text { of } \beta 5 \%\end{array}$ \\
\hline $\mathrm{NPF}_{\mathrm{t}}$ & $\begin{array}{l}\text { Non-Performing Financing } \\
\text { ratio to total Islamic banking } \\
\text { financing in month } t\end{array}$ & Per cent (\%) & $\begin{array}{l}1 \% \text { increase in NPFt, cateris } \\
\text { paribus, will result in a change in } \\
\mathrm{BOPO}_{\mathrm{t}} \text { of } \alpha 1 \%\end{array}$ \\
\hline $\mathrm{CAR}_{\mathrm{t}}$ & Capital Adequacy Ratio of & Per cent (\%) & A $1 \%$ increase in $\mathrm{CAR}_{\mathrm{t}}$, cateris \\
\hline
\end{tabular}

Table 1

Operational Definition and Variable Information

Published by University of Airlangga.

This is an open access article under the CC BY license (https://creativecommons.org/licenses/by-nc-sa/4.0/) 


\begin{tabular}{|c|c|c|c|}
\hline Variable & Operational definition & Unit & Coefficient Information \\
\hline & Islamic banking in month $\mathrm{t}$ & & $\begin{array}{l}\text { paribus, will result in a change in } \\
\text { BOPOt of } \alpha 2 \%\end{array}$ \\
\hline LN_Office ${ }_{t}$ & $\begin{array}{l}\text { Natural logarithm of the } \\
\text { number of Islamic banking } \\
\text { office networks in month } t\end{array}$ & Unit & $\begin{array}{l}1 \% \text { increase in } \text { Office }_{t}=1 \% \text { growth } \\
\text { of office network, cateris paribus, } \\
\text { will result in a } \mathrm{BOPO}_{t} \text { change of ( } \alpha 3 \\
/ 100) \%\end{array}$ \\
\hline$L N \_I P I_{t}$ & $\begin{array}{l}\text { Natural logarithm of the } \\
\text { Industrial Production Index } \\
\text { in the month } t \rightarrow \text { Proxy of } \\
\text { the output level in the } \\
\text { economy }\end{array}$ & Unit (Index) & $\begin{array}{l}1 \% \text { increase in } \mathrm{IPI}_{\mathrm{t}}=1 \% \text { economic } \\
\text { growth, cateris paribus, will result } \\
\text { in a change in NPFt of }(\beta 1 / 100) \%\end{array}$ \\
\hline $\mathrm{LN}_{-} \mathrm{CPI} \mathrm{I}_{\mathrm{t}}$ & $\begin{array}{l}\text { Natural logarithm of the } \\
\text { Consumer Price Index in } \\
\text { month } t \rightarrow \text { Proxy of the } \\
\text { price level in the economy }\end{array}$ & Unit (Index) & $\begin{array}{l}1 \% \text { increase in } \mathrm{CPI}_{\mathrm{t}}=1 \% \text { inflation, } \\
\text { cateris paribus, will result in a } \\
\text { change in } \mathrm{NPF}_{t} \text { of }(\beta 2 / 100) \%\end{array}$ \\
\hline LN_EXR & $\begin{array}{l}\text { Natural logarithm of the } \\
\text { Rupiah Exchange Rate }\end{array}$ & Rp/1USD & $\begin{array}{l}1 \% \text { increase } \mathrm{EXR}_{\mathrm{t}}=1 \% \text { rupiah } \\
\text { depreciation, cateris paribus, will }\end{array}$ \\
\hline & $\begin{array}{l}\text { against the United States } \\
\text { Dollar (Exchange Rate) in } \\
\text { month } t\end{array}$ & & $\begin{array}{l}\text { result in a change in } N^{2} F_{t} \text { of }(\beta 3 / \\
100) \%\end{array}$ \\
\hline $\mathrm{LN}_{\text {_Financing }} \mathrm{t}$ & $\begin{array}{l}\text { Natural logarithm of the } \\
\text { total outstanding Islamic } \\
\text { banking financing in month } t\end{array}$ & Billion Rp & $\begin{array}{l}1 \% \text { increase in Financing }=1 \% \\
\text { growth in outstanding amount, } \\
\text { cateris paribus, will result in a } \\
\text { change in NPFt of }(\beta 4 / 100) \%\end{array}$ \\
\hline
\end{tabular}

\section{RESULT AND ANALYSIS}

Before the TSLS model interpretation was carried out, several diagnostic tests or classical assumption tests were carried out to ensure that the two proposed models could be used for further analysis. The classic assumption tests used in the TSLS model were as follows: First, The autocorrelation test used the Breusch-Godfrey test on both models, the result is the p-value of chi-square, both in the BOPO model $(0.0221)$ and the NPF model (0.0158), was below the trust level or $\alpha(0.05)$. It means the null hypothesis (HO) that stated there was no autocorrelation can be rejected. Thus, the TSLS model above experienced autocorrelation problems.

Table 2

The TSLS Model Autocorrelation Test Results

\section{Breusch-Godfrey Serial Correlation LM Test:}

\begin{tabular}{|c|c|c|c|c|}
\hline BOPO model & Obs*R-squared & 7.62492 & Prob. Chi-Square(2) & 0.0221 \\
\hline NPF Model & Obs*R-squared & 8.299961 & Prob. Chi-Square(2) & 0.0158 \\
\hline
\end{tabular}

Source: Data Processed

Second, The Heteroscedasticity test used the Breusch-Pagan test, the p-value of the F-statistic in the BOPO model (0.0016) was below $\alpha(0.05)$, while the $p$-value of the Fstatistic in the NPF model (0.2008) was above $\alpha(0.05)$. Then, the null hypothesis ( $\mathrm{HO})$ that stated there was no heteroscedasticity can be rejected in the BOPO model but 
cannot be rejected in the NPF model. It means that the TSLS model has heteroscedasticity problems in the BOPO model.

Table 3

The TSLS Model Heteroscedasticity Test Results

\begin{tabular}{lllll}
\hline \multicolumn{5}{c}{ Heteroskedasticity Test: Breusch-Pagan-Godfrey } \\
\hline BOPO Model & F-statistic & 5.437734 & Prob. F(3,116) & 0.0016 \\
NPF Model & F-statistic & 1.483131 & Prob. F(5,114) & 0.2008 \\
\hline
\end{tabular}

Source: Data Processed

The consequence of the heteroscedasticity problem in the BOPO model and autocorrelation in the two models was, it is necessary to make slight changes to the model, especially in the Coefficient Covariance Matrix aspect from ordinary to White to eliminate heteroscedasticity and autocorrelation problems.

Third, endogeneity test ensures that the NPF is the right variable as an endogenous variable. The endogeneity test was carried out by using the J-Statistic test by treating the NPF variable as an exogenous variable in the BOPO model and treating the BOPO variable as an exogenous variable in the NPF model. The BOPO model and the NPF model (0.000) was smaller than $\alpha(0.05)$. Then, the null hypothesis ( $\mathrm{HO})$ that stated NPF and BOPO were exogenous variables can be rejected. Thus, NPF and BOPO have been properly used as endogenous variables in the two TSLS models.

Table 4

Endogeneity Test Results for the NPF Variable in the TSLS Model

\begin{tabular}{ccccc}
\hline & \multicolumn{4}{c}{ Endogeneity Test } \\
\cline { 2 - 5 } & & Value & df & Probability \\
\hline NPF on the BOPO model & Difference in J-stats & 20.64472 & 1 & 0.0000 \\
BOPO on the NPF model & Difference in J-stats & 18.63294 & 1 & 0.0000 \\
\hline Source: Data Processed & & &
\end{tabular}

Source: Data Processed

After testing the classic assumptions of the TSLS model, an interpretation of the TSLS model has been changed. The BOPO model of the TSLS regression results was shown in the following table:

Table 5

Estimation Results of the TSLS Regression BOPO Model

\begin{tabular}{crrrr}
\hline \multicolumn{5}{c}{ Dependent Variable: BOPO } \\
\hline Independent variable & Coefficient & Std. Error & t-Statistics & Prob. \\
LN_OFFICE & 9.849662 & 2.682833 & 3.67136 & 0.0004 \\
NPF & 8.245004 & 0.545384 & 15.11779 & 0.0000 \\
CAR & 0.558766 & 0.129388 & 4.318534 & 0.0000 \\
C & -30.747 & 20.57975 & -1.49404 & 0.1379 \\
\hline R-squared & 0.744858 & & & \\
F-statistics & 99.19880 & & & \\
Prob(F-statistics) & 0.000000 & &
\end{tabular}

Published by University of Airlangga.

This is an open access article under the CC BY license (https://creativecommons.org/licenses/by-nc-sa/4.0/) 
Based on the regression results in the table above, it could be seen that the efficiency of Islamic banking represented by BOPO was significantly and positively influenced by NPF, LN_OFFICE, and CAR as shown by the sign on the positive coefficient and the $p$-value of the three independent variables which were below $\alpha(0.05)$.

Each $1 \%$ increase in the proportion of NPF to total financing will increase the BOPO by $8.25 \%$. Meanwhile, a $1 \%$ growth in the Islamic banking office network will increase the BOPO by $0.098 \%$ (9.8/100). Furthermore, a $1 \%$ increase in CAR will increase BOPO by $0.55 \%$.

Besides, the overall model significance level shown by the F-statistic showed a remarkably high value (99.2) and a p-value (0.0000) which was below $\alpha(0.05)$. This result suggested that the overall model significantly explained the factors affecting BOPO. This condition was in line with the adjusted $\mathrm{R}$-Squared value, which reached 0.744 . It means that the TSLS model above had covered $73.6 \%$ of the factors related to BOPO.

Moreover, the NPF model of the TSLS regression results was shown in the following table:

Table 6

Estimation Results of the TSLS Regression NPF Model

\begin{tabular}{|c|c|c|c|c|}
\hline \multicolumn{5}{|c|}{ Dependent Variable: NPF } \\
\hline Independent variable & Coefisien & Std. Error & t-Statistics & Prob. \\
\hline LN_IPI & 3.806779 & 1.627625 & 2.338855 & 0.0211 \\
\hline LN_FINANCING & -0.5396 & 0.425593 & -1.26787 & 0.2074 \\
\hline LN_EXR & -2.87657 & 1.353479 & -2.12531 & 0.0357 \\
\hline LN_CPI & -1.36039 & 2.389195 & -0.56939 & 0.5702 \\
\hline BOPO & 0.173828 & 0.019336 & 8.989767 & 0.0000 \\
\hline $\mathrm{C}$ & 10.62915 & 5.786449 & 1.836904 & 0.0688 \\
\hline R-squared & 0.728892 & & & \\
\hline F-statistics & 48.39415 & & & \\
\hline Prob(F-statistics) & 0.000000 & & & \\
\hline
\end{tabular}

Source: Data Processed

Based on the table above, NPF as a proxy for Islamic banking performance was significantly influenced by the LN_IPI (proxy for economic growth) with a positive direction, LN_EXR (proxy for growth in the exchange rate of USD against Rupiah) with a negative direction, and BOPO (proxy for Islamic banking efficiency) with a positive relationship direction. This was indicated by the $p$-value of each variable above, which was below $\alpha$ (0.05). Meanwhile, other variables had an insignificant impact on NPF.

The LN_IPI variable as a proxy for economic growth, if it increases by $1 \%$, means that economic growth of $1 \%$ will encourage an increase in the NPF ratio by $0.038 \%$ (3.8/100). An increase in USD against the rupiah is $1 \%$, meaning that a $1 \%$ depreciation of the rupiah will reduce the NPF by $0.0288 \%(2.88 / 100)$. Meanwhile, an increase in the BOPO ratio of $1 \%$ will increase the proportion of NPF by $0.17 \%$.

The findings above were consistent with previous research which states that: 
1. Islamic banks have strong fundamental strengths, which focus on developing micro sector financing. This proves that the microfinance sector has the resilience to crises. On the other hand, Islamic banks only have a small share. This needs attention. Regardless this study was completed and analyzed quantitatively and used before 2021. The government and other relevant stakeholders have merged several Islamic banks. it is hoped that this will capitalize on financing in general, and microfinance in particular. Because we all know that the largest business sector in Indonesia is small, micro, and medium enterprises. The strong fundamental is shown by FDR, as said by Ryandono and Ridlwan (2020). The financing distribution ratio has an average value of 80 per cent, meaning that the Islamic Business Unit is still in great demand by customers. Besides, NPF is only around 2.5 per-cent.

2. There are many Islamic bank branch offices; it turns out that it adds to the operational burden that must be borne by internal parties. Thus, this causes the operating expenses to swell, expansion is hampered, and the pace of development of Islamic banking assets is also distracted. Under these conditions, the concept of business development is offered not to directly construct buildings as branch offices, but to utilize institutions at the regional level such as cooperatives and zakat institutions to open new financial networks at the lower level.

3. A high NPF also affects the higher the value of the BOPO ratio of the Islamic bank itself. At the same time, if Islamic banking is inefficient with a high BOPO ratio, it is prone to make the NPF ratio high. High economic growth can reduce the quality of Islamic banking financing, namely a higher NPF ratio. The prudential aspect of Islamic banking management when the economy is experiencing a boom must be a serious concern, as said by Damanhur et al. (2018). Rupiah depreciation has the potential to reduce NPF in Islamic banking. This is possible when Islamic banking serves exporter customer segment, so if the rupiah weakens, export commodities will become more competitive, and the performance of exporters can be better. NPF as a measure of Islamic banking financing quality is also significantly influenced by several factors, both factors originating from macroeconomic conditions and the operational conditions of Islamic banking itself. Macroeconomic conditions, particularly economic growth, and the strengthening of the rupiah exchange rate against the US dollar, tend to increase the NPF ratio in Islamic banking. At the same time, if the BOPO ratio has increased, the NPF ratio of Islamic banking also tends to increase. In other words, inefficiency in Islamic banking can reduce the quality of Islamic banking financing. 


\section{CONCLUSION}

It is found that high FDR does not guarantee high levels of Islamic banking income and profit. The high BOPO in Islamic banks occurs because of the high operational costs, which after being traced through the observation of the high operational costs caused by each Islamic bank wanting to open a new branch tend to create new buildings which will obviously cost money and reduce business profits. On this basis, a business development strategy can be carried out in the form of cooperation with cooperatives, microfinance institutions or zakat institutions at the regional level, with a lease or syirkah scheme. This will reduce the operational burden, while still being able to target new segmentation in the regions. So that FDR remains high but BOPO can be suppressed.

This study extends the reach of the literature by examining the interaction between macroeconomic conditions, the quality of Islamic banking financing, and the efficiency of Islamic banking. The efficiency of Islamic banking, as measured by operating expense to operating income (BOPO) ratio, is significantly influenced by the nonperforming financing (NPF) ratio, which reflects the financing quality, the number of Islamic banking offices, and the capital adequacy ratio of Islamic banking with a positive relationship. Several recommendations from the results of this study are as follows: (1) the increase in NPF causes high BOPO in Islamic banking; (2) NPF itself, as one of the factors of BOPO, is significantly influenced by economic growth, the strengthening of the rupiah exchange rate, and BOPO; (3) other aspects that encourage NPF, such as prudence in the provision of financing and the pro-cyclical nature of the bank so that it provides more massive funding when the economy is growing, needs to be better regulated.

\section{ACKNOWLEDGMENT}

We would like to thank to data provider website and all the informants who have participated in the forum through various online discussion platforms for giving valuable contributions to this article. We also thank the reviewers who have provided suggestions for improving this paper. This study was conducted to provide an overview and at the same time refer to stakeholders to maximize the company's revenue and profits (Islamic banking), by not building physical facilities in the form of assets but choosing to monitor zakat institutions and cooperatives in the province and district level, which aims to reduce operational costs.

\section{REFERENCES}

Akpan, M. N. U., Aik, N. C., Wanke, P. F., \& Chau, W. H. (2018). Exploring the long-term trade-off between efficiency and value creation in horizontal M\&As: Evidence from Nigeria. African Journal of Economic and Management Studies, 9(2), 130-147. 
https://doi.org/10.1108/AJEMS-06-2017-0139

Altunbas, Y., Liu, M. H., Molyneux, P., \& Seth, R. (2000). Efficiency and risk in Japanese banking. Journal of Banking and Finance, 24(10), 1605-1628. https://doi.org/10.1016/S0378-4266(99)00095-3

Alwi, A. B. (2018). Pembiayaan Berbasis Teknologi Informasi (Fintech) yang Berdasarkan Syariah. Al-Qānūn, 21(2), 255-271.

Asteriou, D., \& Hall, S. G. (2007). Applied Econometrics, A Modern Approach (Revised Edition). Palgrave Macmillan.

Aulia, M., Yustiardhi, A. F., \& Permatasari, R. O. (2020). An overview of Indonesian regulatory framework on Islamic financial technology (fintech). Jurnal Ekonomi \& Keuangan Islam, 6(1), 64-75. https://doi.org/10.20885/jeki.vol6.iss1.art7

Bank Indonesia. (2011). Peraturan Bank Indonesia Nomor: 13/1/PBI/2011 Tentang Penilaian Tingkat Kesehatan Bank Umum. Peraturan Bank Indonesia, 1-31.

Beck, T., Demirgüç-Kunt, A., \& Merrouche, O. (2013). Islamic vs. conventional banking: Business model, efficiency and stability. Journal of Banking and Finance, 37(2), 433447. https://doi.org/10.1016/j.jbankfin.2012.09.016

Chitnis, A., \& Vaidya, O. S. (2018). Efficiency ranking method using SFA and TOPSIS (ERMST): case of Indian banks. Benchmarking, 25(2), 471-488. https://doi.org/10.1108/BIJ-08-2016-0126

Cucinelli, D. (2016). Can speed kill?: The cyclical effect of rapid credit growth: evidence from bank lending behavior in Italy. Journal of Risk Finance, 17(5), 562-584. https://doi.org/10.1108/JRF-03-2016-0035

Damanhur, Albra, W., Syamni, G., \& Habibie, M. (2018). What is the Determinant of NonPerforming Financing in Branch Sharia Regional Bank in Indonesia. 1, 265-271. https://doi.org/10.1108/978-1-78756-793-1-00081

Dhal, S., \& Misra, B. (2014). Pro-cyclical Management of Banks' NonPerforming Loans by the Indian Public Sector Banks Pro-cyclical Management of Banks' Non -Performing Loans by the Indian Public Sector Banks. RBI Occasional Papers, March, 1-23.

Ding, D., \& Sickles, R. C. (2019). Capital Regulation, Efficiency, and Risk Taking: A Spatial Panel Analysis of US Banks. Panel Data Econometrics, 2, 405-466. https://doi.org/10.1016/b978-0-12-815859-3.00013-5

Effendi, J., Thiarany, U., \& Nursyamsiah, T. (2017). Factors Influencing Non-Performing Financing (NPF) at Sharia Banking. Walisongo: Jurnal Penelitian Sosial Keagamaan, 25(1), 109-138. https://doi.org/10.21580/ws.25.1.1540

Fatmawati, A., Yudha, A. T. R. C., \& Syafaq, H. (2020). Kontrak Kerja dan Kesejahteraan ABK Nelayan Perspektif Etika Bisnis Islam di Sarangmerduro, Jawa Tengah. Nukhbatul 'Ulum: Jurnal Bidang Kajian Islam, 6(2), 298-313.

Firianingsih, N. (2017). Analisis Perbandingan Efisiensi Bank Umum Syariah dan Bank Umum Konvensional dengan Metode Data Evelopment Analysis (DEA) periode 2010-2014. Вестник Росздравнадзора.

Ghosh, A. (2017). Impact of non-performing loans on US product and labor markets. Journal of Financial Economic Policy, 9(3), 302-323. https://doi.org/10.1108/JFEP- 
01-2017-0003

Habibi, M. L., \& Yudha, A. T. R. C. (2017). Membangun Integrated Takaful Dan Wakaf Model Dalam Upaya Meningkatkan Kemanfaatan Pemegang Polis. Al-Uqud : Journal of Islamic Economics, 1(2), 139. https://doi.org/10.26740/jie.v1n2.p139-155

Hadisumarto, W. B. M. C., \& Ismail, A. G. B. (2010). Improving the effectiveness of Islamic micro-financing: Learning from BMT experience. Humanomics, 26(1), 65-75. https://doi.org/10.1108/08288661011025002

Haleem, A., \& Khan, M. I. (2017). Towards successful adoption of Halal logistics and its implications for the stakeholders. British Food Journal, 119(7), 1592-1605. https://doi.org/10.1108/BFJ-12-2016-0637

Hardianto, D. S., \& Wulandari, P. (2016). Islamic bank vs conventional bank: intermediation, fee based service activity and efficiency. International Journal of Islamic and Middle Eastern Finance and Management., 9(2), 296-311.

https://doi.org/10.1108/IMEFM-01-2015-0003

Hassan, Y., \& Sengupta, A. (2019). India - an untapped market for halal products. Journal of Islamic Marketing, 10(3), 981-1002. https://doi.org/10.1108/JIMA-09-2018-0179

Hazera, A., Quirvan, C., \& Marin-Hernandez, S. (2016). The impact of guaranteed bailout assistance on bank loan overstatement: The Mexican financial crisis of the late 1990s and early 2000s. International Journal of Managerial Finance, 12(2), 177-210. https://doi.org/10.1108/IJMF-04-2014-0046

Hess, K., \& Francis, G. (2004). Cost income ratio benchmarking in banking: A case study. Benchmarking, 11(3), 303-319. https://doi.org/10.1108/14635770410538772

Ilmu, L., \& Indonesia, P. (2012). Dan Konvensional Di Indonesia Comparison Efficiency Analysis of Islamic and. 183-193.

Indrawati, S. M., Diop, N., Ikhsan, M., \& Kacaribu, F. (2020). Enhancing Resilience to Turbulent Global Financial Markets: An Indonesian Experience. ... and Finance in Indonesia, 66(1), 47-63.

Isa, M. Y. M., \& Rashid, M. Z. H. A. (2018). Regulatory capital funds and risk-sharing behavior in distressed financial conditions: An empirical analysis on Islamic banks in Malaysia. Journal of Financial Reporting and Accounting, 16(1), 197-216. https://doi.org/10.1108/JFRA-06-2015-0066

Lee, S. P., \& Isa, M. (2017). Determinants of bank margins in a dual banking system. Managerial Finance, 43(6), 630-645. https://doi.org/10.1108/MF-07-2016-0189

Lotto, J. (2019). Evaluation of factors influencing bank operating efficiency in Tanzanian banking sector. Cogent Economics and Finance, 7(1). https://doi.org/10.1080/23322039.2019.1664192

Miah, M. D., \& Uddin, H. (2017). Efficiency and stability: A comparative study between islamic and conventional banks in GCC countries. Future Business Journal, 3(2), 172185. https://doi.org/10.1016/j.fbj.2017.11.001

Muljawan, D., Hafidz, J., Astuti, R. I., \& Oktapiani, R. (2014). Faktor-Faktor Penentu Efisiensi Perbankan Indonesia serta Dampaknya terhadap Perhitungan Suku Bunga Kredit. Working Paper Bank Indonesia, WP/2/2014, 1-77.

Murti, T. W. (2017). Halal Life Style And Global Trade. The 7th International Seminar on Tropical Animal Production Contribution of Livestock Production on Food 
Sovereignty in Tropical Countries, 2, 33-39.

Nguyen, Q. T. T., Nguyen, S. T. B., \& Nguyen, Q. V. (2019). Can Higher Capital Discipline Bank Risk: Evidence from a Meta-Analysis. Journal of Risk and Financial Management, 12(3), 134. https://doi.org/10.3390/jrfm12030134

Noman, A. H. M., Gee, C. S., \& Isa, C. R. (2017). Does competition improve financial stability of the banking sector in ASEAN countries? An empirical analysis. PLOS ONE, 12(5), 1-27. https://doi.org/10.1371/journal.pone.0176546

Noordin, N. H., Haron, S. N., \& Kassim, S. (2017). Developing a comprehensive performance measurement system for waqf institutions. International Journal of Social Economics, 44(7), 921-936. https://doi.org/10.1108/IJSE-09-2015-0257

Olson, D., \& A. Zoubi, T. (2014). The determinants of loan loss and allowances for MENA banks: Simultaneous equation and three-stage approaches. Journal of Islamic Accounting and Business Research, 5(1), 98-120. https://doi.org/10.1108/JIABR-072013-0027

Pan, X., Dresner, M., \& Xie, Y. (2019). Logistics IS resources, organizational factors, and operational performance: An investigation into domestic logistics firms in China. International Journal of Logistics Management, 30(2), 569-594. https://doi.org/10.1108/IJLM-02-2018-0023

Pham, T. P., Popesko, B., Quddus, A., \& Nguyen, N. T. K. (2021). Innovation and Bank Efficiency in Vietnam and Pakistan. Scientific Papers of the University of Pardubice, Series D: Faculty of Economics and Administration, 29(2), 1-11. https://doi.org/10.46585/sp29021184

Phan, H. T. M., Daly, K., \& Akhter, S. (2016). Bank efficiency in emerging Asian countries. Research in International Business and Finance, 38, 517-530. https://doi.org/10.1016/j.ribaf.2016.07.012.

Pinochet, L. H. C., Diogo, G. T., Lopes, E. L., Herrero, E., \& Bueno, R. L. P. (2019). Propensity of contracting loans services from FinTech's in Brazil. International Journal of Bank Marketing, 37(5), 1190-1214. https://doi.org/10.1108/IJBM-072018-0174

Ponziani, R. M. , \& Mariyanti, T. (2020). Islamic Bank and Monetary Policy: The Case of Indonesia. International Journal of Islamic Economics and Finance (IJIEF), 3(1), 121142. https://doi.org/10.18196/ijief.2124

Prahasty, D. R., \& Misdiyono. (2020). The Effects of Third Party Fund, Interest Rates, Bank Capital, and Non-Performing Loan towards Credit Dustribution on Commercial Bank in Indonesia period 2012-2018. International Journal of Advance Study and Research Work, 3(5), 22-29, (2581-5997). https://doi.org/10.5281/zenodo.3843656

Rabab'ah, M. (2015). Factors Affecting the Bank Credit: An Empirical Study on the Jordanian Commercial Banks. International Journal of Economics and Finance, $7(5)$, 166-178. https://doi.org/10.5539/ijef.v7n5p166

Rahmah, A. Z., \& Armina, S. H. (2020). Macro and micro determinants of the nonperforming finance: The case of Indonesian Islamic bank. Jurnal Ekonomi \& Keuangan Islam, 6(1), 34-41. https://doi.org/10.20885/jeki.vol6.iss1.art4 
Ramanathan, R., Ramanathan, U., \& Bentley, Y. (2018). The debate on flexibility of environmental regulations, innovation capabilities and financial performance $-A$ novel use of DEA. Omega (United Kingdom), 75, 131-138. https://doi.org/10.1016/j.omega.2017.02.006

Roy, A., \& Goswami, C. (2013). A scientometric analysis of literature on performance assessment of microfinance institutions (1995-2010). International Journal of Commerce and Management, 23(2), 148-174. https://doi.org/10.1108/10569211311324939

Ryandono, M. N. H., \& Ridlwan, A. A. (2020). Solution for Islamic Banks Exploitation: A Criticism of Fixed-Yields Based Financing in Indonesia. Al-Uqud: Journal of Islamic Economics, 4(1), 48-68. https://doi.org/10.26740/al-uqud.v4n1.p48-68

Sadari, S., \& Hakim, A. (2019). Revitalisasi Keuangan Inklusif Dalam Sistem Perbankan Syariah Di Era Financial Technology. Journal of Islamic Economics, Finance, and Banking.

Şan, T. (2016). The Effects of the Changes in Some Macroeconomic Indicators on the Non - Performing Loans in the Albanian Banking Sector (2007 - 2014). Mediterranean Journal of Social Sciences, 7(3), 162-170. https://doi.org/10.5901/mjss.2016.v7n3p162

Sukoco, A., Anshori, Y., \& Yudha, A. T. R. C. (2020). Strategies To Increase Market Share For Histopatological Equipment Products (Brand Sakura): Case Study in Management of a Sole Agent Company. SINERGI, Volume 10 Number 2 September 2020 SINERGI , Volume 10 Number 2 September 2020, 10(2), 19-26.

Wardiwiyono, S. (2012). Internal control system for Islamic micro financing: An exploratory study of Baitul Maal wat Tamwil in the City of Yogyakarta Indonesia. International Journal of Islamic and Middle Eastern Finance and Management, 5(4), 340-352. https://doi.org/10.1108/17538391211282836

Yalina, N., Kartika, A. P., \& Yudha, A. T. R. C. (2020). Impact Analysis of Digital Divide on Food Security and Poverty in Indonesiain 2015-2017. Jurnal Manajemen Teknologi, 19(2), 145-158. https://doi.org/http://dx.doi.org/10.12695/jmt.2020.19.2.3

Yin, Z., Yu, Y., \& Huang, J. (2018). Evaluation and evolution of bank efficiency considering heterogeneity technology: An empirical study from China. PLOS ONE, 13(10), 1-19. https://doi.org/10.1371/journal.pone.0204559

Yudha, A. T. R. C., Pauzi, N. S., \& Azli, R. binti M. (2020). The Synergy Model for Strengthening the Productivity of Indonesian Halal Industry. 4(28), 186-199. https://doi.org/10.26740/al-uqud.v4n2.p186-199

Yudha, A. T. R. C., Ryandono, M. N. H., Rijal, A., \& Wijayanti, I. (2020). Financing model to develop local commodity business of East Java in Maqashid Syariah perspective. Test Engineering and Management, 83(3590), 3590-3595.

Zaki, I., Widiastuti, T., Yudha, A. T. R. C., Wijayanti, I., \& Mi'raj, D. A. (2020). Implementation of Islamic entrepreneurial culture in Islamic boarding schools. International Journal of Innovation, Creativity and Change, 11(11), 452-469. 